\title{
APPLICATION OF PETRI NETS METHODOLOGY TO DETERMINE BIOPHYSICOCHEMICAL PARAMETERS OF MITOCHONDRIA FUNCTIONING
}

\author{
H. V. DANYLOVYCH ${ }^{\varpi}$, A. Yu. CHUNIKHIN, \\ Yu. V. DANYLOVYCH, S. O. KOSTERIN \\ Palladin Institute of Biochemistry, National Academy of Sciences of Ukraine, Kyiv; \\ e-mail: danylovych@biochem.kiev.ua
}

Received: 01 Nobember 2020; Accepted: 17 May 2021

With the use of Petri net methodology a mathematical simulation model able to predict simultaneous changes in biophysicochemical parameters of mitochondria functioning was developed. The model allowed to interconnect in time the changes in mitochondria hydrodynamic diameter, electronic transport chain functioning, endogenous fluorescence of adenine nucleotides, DCF fluorescence signal of ROS production and $\mathrm{NaN}_{3}$ effects. It was shown that the calculated values of the studied biophysicalchemical parameters correspond to those obtained experimentally. The model permit to link mitochondrial functional changes and their structural representation and to optimize significantly experimental procedures.

Key word s: Petri nets, mathematical modeling, mitochondria, electronic transport chain, nitric oxide.

$\mathrm{B}$ iochemistry and molecular physiology of mitochondria, which combines the processes of oxygen consumption, oxidative phosphorylation, catabolism of lipids, biosynthesis of heme, maintenance of $\mathrm{Ca}^{2+}$ homeostasis, production of reactive oxygen and nitrogen species, apoptosis, etc. are the priority directions of modern biological science [1-3]. Further elucidation of the electronic transport chain functioning mechanisms and ways of breaking mitochondrial bioenergetics is important for understanding the causes and effects of mitochondrial dysfunction, which is the basis of the smooth muscles contractile function pathology. In particular, the generation of ATP and the functioning of low-affinity and high-capasitive $\mathrm{Ca}^{2+}$ uniporter significantly affects the path of $\mathrm{Ca}^{2+}$ signaling in myocytes and is an important factor in reducing the concentration of this cation in the myoplasm after the $\mathrm{Ca}^{2+}$ transient [4-5]. This also applies to the mitochondria of the uterus smooth muscle, where the electrochemical gradient dissipation of the internal membrane leads to a generalized increase in the myoplasm concentration of $\mathrm{Ca}^{2+}[6]$. Inhibitors of some complexes of the respiratory chain are widely used in order to study thise.

Biomarkers of mitochondria functional activity are parameters such as the endogenous fluorescence signal from adenine nucleotides (NADH), the volume of mitochondria (hydrodynamic diameter), the intensity of reactive oxygen species production (DCF fluorescence), the efficiency of the $\mathrm{Ca}^{2+}$ accumulation, etc [4, 7-11]. The possibility of simultaneous simulation of these processes is important for understanding the functioning of mitochondria as a holistic system and will enable to predict the consequences of the violation of certain electronic transport chain components for bioenergy, $\mathrm{Ca}^{2+}$ homeostasis and programmed cell death. In particular, it seems advisable to construct a model based on data from the known inhibitor of the IV complex of the respiratory chain and the "indirect NO donor" [12] sodium azide action on the biophysicochemical parameters of the mitochondria. The actuality of this work is due to the widespread use of $\mathrm{NaN}_{3}$ as a tool for inhibiting oxidative phosphorylation and transport functions of mitochondria, as well as the

(C) 2021 Danylovych H. V. et al. This is an open-access article distributed under the terms of the Creative Commons Attribution License, which permits unrestricted use, distribution, and reproduction in any medium, provided the original author and source are credited. 
possibility of endogenous synthesis of NO in these subcellular structures.

We are developing a simulation model that links changes in the functioning of the electronic transport chain, the production of reactive oxygen species, the endogenous fluorescence of adenine nucleotides, and mitochondria swelling for the formalization and generalization of experimental data, in order to carry out the predictive function, and also to find the correspondence between the theoretical predictions and real results. We use the methodology of hybrid functional Petri nets as a modeling tool. The advantages of hybrid functional Petri nets as a modeling method include the following [13]: (1) capability to structurally represent the states of the modeled system and the processes occurring in the system; (2) quantitative modeling of three types of states and processes simultaneously, namely discrete, continuous, and associative (forming); (3) possibility to consider the activating, inhibiting, and catalytic effects by the means of a special type of bonds.

The aim of the paper was to use Petri nets to create an imitation model for simultaneous changes in the fluorescence of endogenous $\mathrm{NADH}$, the characteristic size of mitochondria and the generation of reactive oxygen species in real experimental conditions, which would combine functional changes with the structural representation of these processes.

\section{Materials and Methods}

Experiments were performed on white wildtype nonpregnant rats weighing 150-180 g. All manipulations with animals were carried out according to the European Convention for the Protection of Vertebrate Animals used for Experimental and other Scientific Purposes, and the Law of Ukraine "On protection of animals from cruelty". Rats were anesthetized by diethyl ether inhalation and decapitated.

Isolation of mitochondria from the smooth muscle of the uterus (myometrium) of nonpregnant rats. The mitochondrial fraction was isolated from the myometrium of nonpregnant rats using differentiation centrifugation, as described by Kosterin and coworkers [14]. For the duration of the experiment, the isolated mitochondrial fraction was kept on ice. The protein content of the mitochondrial fraction was determined by a standard procedure by Bradford [15]. The total protein content in the mitochondrial fraction was $2 \mathrm{mg} / \mathrm{ml}$.

Registration of DCF-fluorescence in mitochondria. The loading of mitochondria by reactive oxy- gen species sensitive DCF-DA fluorescence probe at a concentration of $25 \mu \mathrm{M}$ was performed in a medium containing $10 \mathrm{mM}$ Hepes ( $\mathrm{pH} 7.4,37^{\circ} \mathrm{C}$ ), $250 \mathrm{mM}$ sucrose, $0.1 \%$ bovine serum albumin for $30 \mathrm{~min}$ at $24^{\circ} \mathrm{C}$. The Pluronic F-127 dye was added $(0.02 \%)$ to improve the loading process. DCF-fluorescence in isolated mitochondria was studied using the flow cytometry method on the COULTER EPICS $\mathrm{XL}^{\mathrm{TM}}$ (Beckman Coulter, USA) equipped with an argon laser $\left(\lambda_{\mathrm{ex}}=488 \mathrm{~nm}, \lambda_{\mathrm{fl}}=525 \mathrm{~nm}\right.$ (Fl1 channel). The incubation medium consisted of $20 \mathrm{mM}$ Hepes ( $\mathrm{pH} 7.4,23^{\circ} \mathrm{C}$ ), $2 \mathrm{mM} \mathrm{K}$-phosphate buffer ( $\mathrm{pH} 7.4$, $23^{\circ} \mathrm{C}$ ), $125 \mathrm{mM} \mathrm{KCl}, 25 \mathrm{mM} \mathrm{NaCl}$. The reaction was initiated by adding aliquots $(20 \mu \mathrm{l})$ of $5 \mathrm{mM}$ pyruvate $+5 \mathrm{mM}$ succinate. Incubation time was $35 \mathrm{~min}$. Sodium azide was added for $15 \mathrm{~min}$. The protein content in the aliquot of the mitochondria fraction was $20-25 \mu \mathrm{g}$.

Estimation of mitochondrial hydrodynamic diameter. To assess changes in the mitochondrial volume, we used the Dynamic light scattering method, which allowed us to determine their sizes (average hydrodynamic diameter). The volume of the particles in suspension was analyzed using the correlation spectrometer ZetaSizer-3 (Malvern Instruments, UK) equipped with He-Ne laser LGN-111 $(\mathrm{P}=25 \mathrm{~mW}, \lambda=633 \mathrm{~nm})$. Its operation principle is based on the analysis of time-dependent fluctuations in the scattering intensity when a laser ray passes through a medium with the mitochondria. The temporal intensity changes are converted into the mean translational diffusion coefficient (D) [16]. The translational diffusion coefficient is related to the duration of the correlation $\tau_{\mathrm{c}}$ with the following ratio:

$$
D q^{2}=1 / \tau_{c}
$$

The wave vector of the concentration fluctuations $(q)$ is described by the following expression:

$$
q=\frac{4 \pi n}{\lambda_{o}} \sin \left(\frac{\theta}{2}\right)
$$

where $n$ is the refractive index of the medium (liquid), $\lambda_{0}$ is the wavelength, and $\theta$ is the scattering angle.

Using the Stokes-Einstein equation that connects the particle size, the translational diffusion coefficient, and the viscosity of the liquid, we could calculate the size (diameter) $\mathrm{d}(H)$ of the spherical particles as follows [16]:

$$
d(H)=\frac{k_{B} \cdot T}{3 \pi \eta D},
$$


where $k_{\mathrm{B}}$ is the Boltzmann constant; $T$ is the absolute temperature, $K ; \eta$ is the shear viscosity of the medium in which the particles are suspended; and $D$ is the translational diffusion coefficient.

The recording and statistical processing of the changes in the scattering intensity in the mitochondria water suspension $(n=1.33)$ were performed 10 times for $10 \mathrm{~min}$ at $22^{\circ} \mathrm{C}$, at a scattering angle of $90^{\circ}$. The obtained results were processed using the PCS-Size mode v1.61 software.

The incubation medium consisted of $20 \mathrm{mM}$ Hepes (pH 7.4, $\left.23^{\circ} \mathrm{C}\right), 2 \mathrm{mM} \mathrm{K}$-phosphate buffer

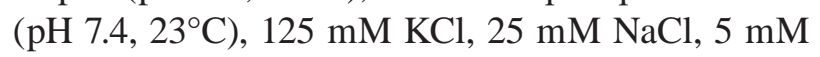
pyruvate, and $5 \mathrm{mM}$ succinate.

Detection of NADH fluorescence in mitochondria using spectrofluorometry. The relative values of NADH intrinsic fluorescence were determined with Quanta Master 40 PTI (Canada) using the FelixGX 4.1.0.3096 software. The detection was conducted in $2 \mathrm{ml}$ of the following medium: $20 \mathrm{mM}$ Hepes (pH 7.4 at $37^{\circ} \mathrm{C}$ ), $2 \mathrm{mM} \mathrm{K}^{+}$-phosphate buffer ( $\mathrm{pH} 7.4$ at $37^{\circ} \mathrm{C}$ ), $125 \mathrm{mM} \mathrm{KCl}, 25 \mathrm{mM} \mathrm{NaCl}, 5 \mathrm{mM}$ pyruvate, and $5 \mathrm{mM}$ succinate. The protein concentration in the sample was $50 \mu \mathrm{g} / \mathrm{ml}$.

Simulation of DCF-fluorescence, mitochondrial swelling and changes in NADH fluorescence. For the simulation, we chose the Cell Illustrator v.3 software (Human Genome Center, University of Tokyo, Japan), the basis of which is a hybrid functional Petri net. A Petri net is a directed bipartite graph with two types of nodes (Table): places and transitions, which are connected by arcs, reflecting the structure of the net. Places usually characterize the objects, elements, and resources of the modeled system; transi- tions are the events that occur in the system and the logical conditions of their implementation [17].

Assessment of the content of ionized calcium in the mitochondria. Loading of the mitochondria by the probe Fluo- $4 \mathrm{AM}$ at a concentration of $2 \mu \mathrm{M}$ was carried out in the medium that contained (mM):

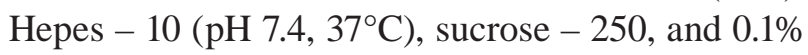
bovine serum albumin for $30 \mathrm{~min}$ at $37^{\circ} \mathrm{C}$. To improve the process, the dye was mixed with Pluronic F-127 (0.02\%). The relative values of $\mathrm{Ca}^{2+}$ content in the matrix of mitochondria, loaded with Fluo-4 $\operatorname{AM}\left(\lambda_{\mathrm{ex}}=490 \mathrm{~nm}, \lambda_{\mathrm{ff}}=520 \mathrm{~nm}\right)$ was investigated using the fluorometric method on spectrofluorimeter Quanta Master PTI 40 (Canada) with software FelixGX 4.1.0.3096. The medium, from which energydependent accumulation of $\mathrm{Ca}^{2+}$ was carried out by the mitochondria, had a composition (mM): $20 \mathrm{mM}$ Hepes (pH 7.4, $37^{\circ} \mathrm{C}$ ), $2 \mathrm{mM} \mathrm{K} \mathrm{K}^{+}$phosphate buffer ( $\mathrm{pH} 7.4,37^{\circ} \mathrm{C}$ ), $250 \mathrm{mM}$ sucrose , $3 \mathrm{mM} \mathrm{MgCl}_{2}$, $3 \mathrm{mM}$ ATP, $5 \mathrm{mM}$ sodium succinate, concentration of $\mathrm{Ca}^{2+}-80 \mu \mathrm{M}$ [18].

In the work the following reagents were used: Hepes, sucrose, sodium succinate, sodium pyruvate, bovine serum albumin, ATP, $\mathrm{NaN}_{3}$, Pluronic F-27, DCF-DA (2',7'-dichlorodihydrofluorescein diacetate), EGTA, $\mathrm{CaCl}_{2}$, A-23187 (Sigma, USA); Fluo-4 AM (Invitrogen, USA). Any other reagents are produced in Ukraine.

The solutions were prepared on bidistilled water, which had a specific electrical conductivity of not more than $2.0 \mu \mathrm{cm} / \mathrm{cm}$. The electrical conductivity of the water was recorded using a conductometer OK-102/1 (Hungary).

Main structural elements of the hybrid functional Petri nets (see the main text for the explanation)

\begin{tabular}{|c|c|c|c|c|}
\hline Type & Places & Transitions & Label & Arcs \\
\hline Discrete & $\begin{array}{l}\text { integer } \\
\text { Discrete place }\end{array}$ & $\begin{array}{l}\text { delay } \\
\text { Discrete transition }\end{array}$ & Normal & $\underset{\text { Normal arc }}{\text { threshold }}$ \\
\hline Continuous & $\begin{array}{l}\text { real number } \\
\text { Continuous place }\end{array}$ & $\begin{array}{l}\square \text { rate } \\
\text { Continuous transition }\end{array}$ & Test & $\begin{array}{l}\text { threshold } \\
-\mathbf{- ~ - ~} \\
\text { Test arc }\end{array}$ \\
\hline Generic & $\bigoplus_{\text {any types }}$ & $\begin{array}{c}\text { Generie transition } \\
\text { Geny operation }\end{array}$ & Inhibitory & $\begin{array}{l}\text { threshold } \\
\text { Inhibitory arc }\end{array}$ \\
\hline
\end{tabular}




\section{Results and Discussion}

We have developed a simulation model (Fig. 1) that connects changes in the endogenous NADH fluorescence (Fig. 2), production of reactive oxygen species (Fig. 3) and mitochondria swelling (Fig. 4) for the formalization of experimental data in this work, in order to carry out the predictive function, and also to find the correspondence between the theoretical predictions and real results. We have used the "indirect donor" of NO sodium azide as a biologically active compound that causes changes in the corresponding biophysicalchemical parameters of the mitochondria (Fig. 3, 4).

It was established, that $\mathrm{NaN}_{3}$ increased the mitochondria hydrodynamic diameter (causing swelling) and amplified their DCF fluorescence (it stimulated the formation of reactive oxygen forms), depending on its concentration (1-3-5-7 $\mathrm{mM}$ ) and time (0-15 min), see Fig. 3, 4. Inhibition of the respiratory chain IV complex results in the slowing down of the mitochondria functioning, the reduction of the electrical and chemical potential on the internal membrane $(\Delta \mathrm{pH})$, the opening of the mitochondrial permeability transition pore (MPTP) and the mitochondria swelling [19-23]. The accumulation in the electron transport chain of the semi-reduction components, especially in Q-cycle, leads to an increase in the process of one-electron oxygen reduction [24]. Thus, the generation of superoxide anion and other reactive oxygen species will be intensified. Simultaneously, the chemical decomposition of sodium azide with the formation of nitrogen oxides will be accompanied by an increase in the generation of peroxynitrite, which contributes to DCF fluorescence too. Strengthening under these conditions the content of reactive nitrogen and oxygen species in mitochondria will further reduce the functional activity of the electron transport chain and matrix enzymes, especially those containing iron-sulfur centers and metal proteins [25-27]. The latter will result in the processes of the mitochondrial dysfunction, collapse of bioenergetics up to cell death [21, 23, 28]. Using Petri hybrid functional nets, we simulated the effect of sodium azide, depending on the time and concentration, on the hydrodynamic diameter and DCF fluorescence of the myometrium isolated mitochondria.

The components of the mitochondria incubation medium and the effects of sodium azide on their biophysicochemical parameters were taken into account in the simulation. We operated the following experimental facts in the process of the model creation: (1) - succinate and pyruvate are added to the mitochondria incubation medium for their energized; (2) - sodium azide, as an "indirect NO donor", has an inhibitory effect on the electronic transport chain as a whole, but the greatest effect on the morphofunctional parameters of the organelles has inhibition of the I, III and IV complexes (3) - inhibition of the electron transport chain activity results in the intensification of the reactive oxygen forms production in the mitochondria and, consequently, DCF fluorescence (direct inhibition of the IV complex within the framework of the simulation model); (4) - inhibition of the electron transport chain by sodium azide leads to an increase in the hydrodynamic diameter of the mitochondria: the osmotic balance between the matrix and the nonmitochondrial medium is broken due to the activation of MPTP with the subsequent $\mathrm{H}_{2} \mathrm{O}$ entrance to the matrix and swelling of the mitochondria (this is the result of inhibition of I, III and IV complexes and depolarization of the internal mitochondrial membrane in the framework of the simulation model).

The structure of hybrid functional Petri nets, which simulated the sodium azide effect on the changes in the hydrodynamic diameter, NADH and DCF fluorescence of the myometrium mitochondria, is presented in the scheme (Fig. 1). Symbols in the scheme are explained in the caption. Some particular specifications are listed below. The place $\mathrm{m} 15$ is a timer that controls the time of the inhibitor insertions in the amount determined by the place m16. Before the insertion of a specific inhibitor of electron transport chain, the mitochondrial hydrodynamic diameter, measured by Zeta-sizer (transition ZS and place $\mathrm{m} 4$ ) practically does not change. The fluorescent response of NADH/DCF is registered by the spectrofluorimeter QM (place m5) and corresponds to the "control" curves (Fig. 2, 3).

The insertion of sodium azide $\left(\mathrm{NO}_{x}\right.$, Fig. 1) breaks the work of electron transport chain that decreases the electric potential of the inner mitochondrial membrane W (place m6). It causes an activation of MPTP, $\mathrm{H}_{2} \mathrm{O}$ transport into the matrix (place $\mathrm{m7}$ ), and an increase in the mitochondrial hydrodynamic diameter. The fluorescence response changes are simulated by the NADH and DCF transitions with velocities in accordance with equations $(5,7)$ as described below.

Through the modeling, we obtained mathematical equations that formalized the process of mito- 


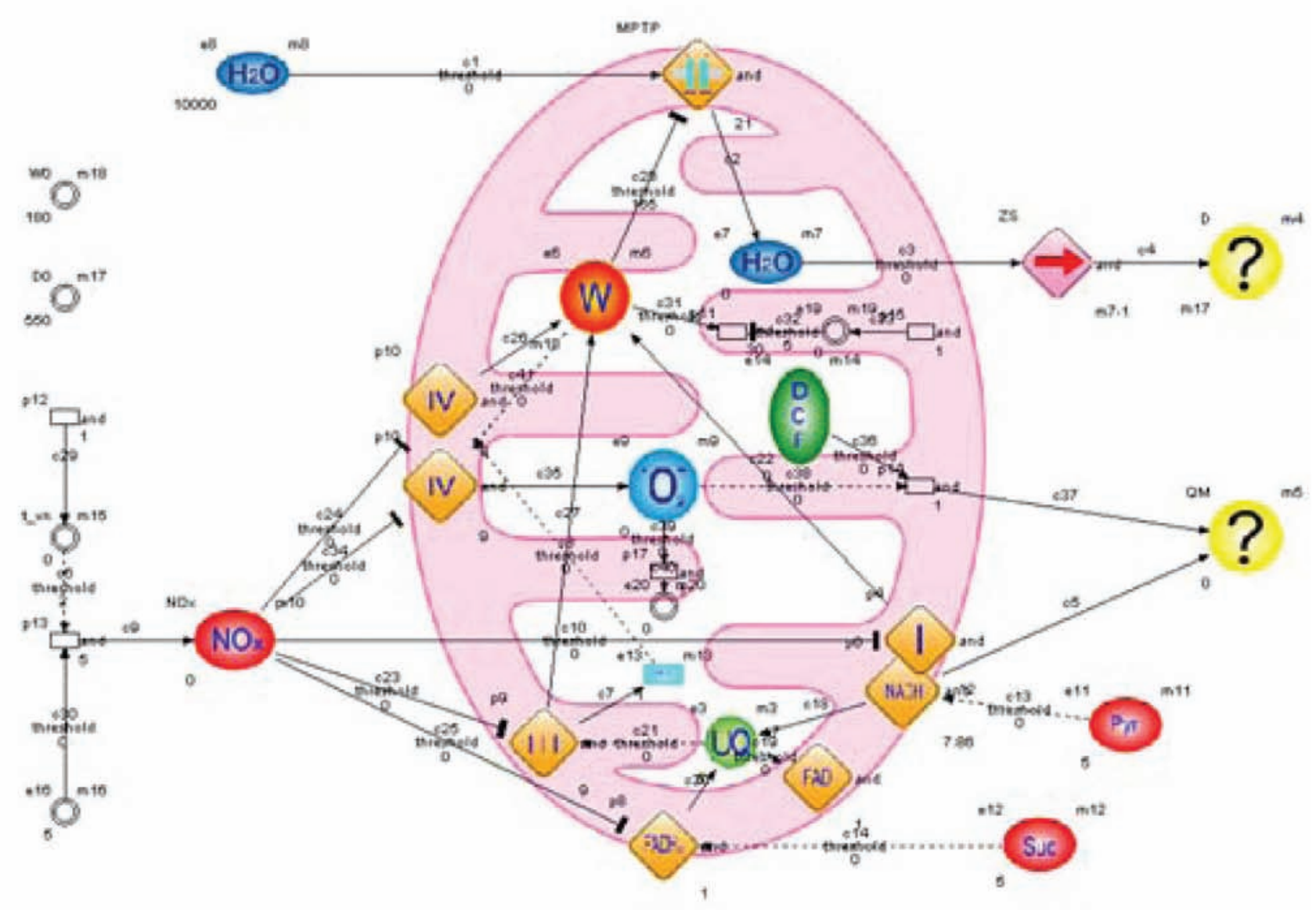

Fig. 1. Structure of hybrid functional Petri nets, which simulated the sodium azide effect on the changes in the hydrodynamic diameter and the NADH, DCF fluorescence of the myometrium mitochondria. Symbols in the scheme: $N O_{x}$ - nitrocompounds, particularly sodium azide; Suc - sodium succinate; Pyr - sodium pyruvate; $W$ - electric potential of the inner mitochondrial membrane; I, II, III, and IV as well as FADH ${ }_{2}, F A D$, and $N A D H$ (inscribed in a rhombus in the mitochondrial membrane) - complexes of the electron transport chain and the appropriate cofactors; $\mathrm{O}_{2}^{--}$- superoxide anion; DCF - DCF-DA fluorescence probe; UQ - ubiquinone; cyt $C$ - cytochrome C; symbol -| | - inside a rhombus - cyclosporine-sensitive permeability transition pore, MPTP; and arrows: $\rightarrow-$ activation of the process and $\mathrm{T}^{-}$-inhibition of the process

chondria swelling and the changes in the NADH/ DCF fluorescence in the medium supplemented with sodium azide. In particular, these equations adequately described the time characteristics of the mitochondria swelling (Fig. 4), changing of the NADH/DCF fluorescence (Fig. 2, 3) simultaneously. The permeability of MPTP and the intensity of the NADH/DCF fluorescent response are the time derivatives from the corresponding dependencies.

The substrate of pyruvate dehydrogenase complex (5 mM pyruvate) that produced NADH for electron transport chain, and $5 \mathrm{mM}$ succinate, a substrate of FAD-dependent succinate dehydrogenase was added to incubation medium in order to pro- duce the energized state of mitochondria [29]. It has been shown that NADH fluorescence decreased in time in the presence of respiratory substrates, which indicates increase in $\mathrm{NAD}^{+}$content resulting from functioning of NADH-ubiquinone oxidoreductase of electron transport chain (Fig. 1). We have used experimental results from reduce the autofluorescence of NADH in isolated mitochondria over time under the condition of the electron transport chain functioning for modeling in this study. The time dependence of the average change in the fluorescent response of NADH (autofluorescence) was approximated by polynomials as follows:

$F n(N A D H)=-0.07 t^{3}+2.54 t^{2}-32.72 t-12.19$. 


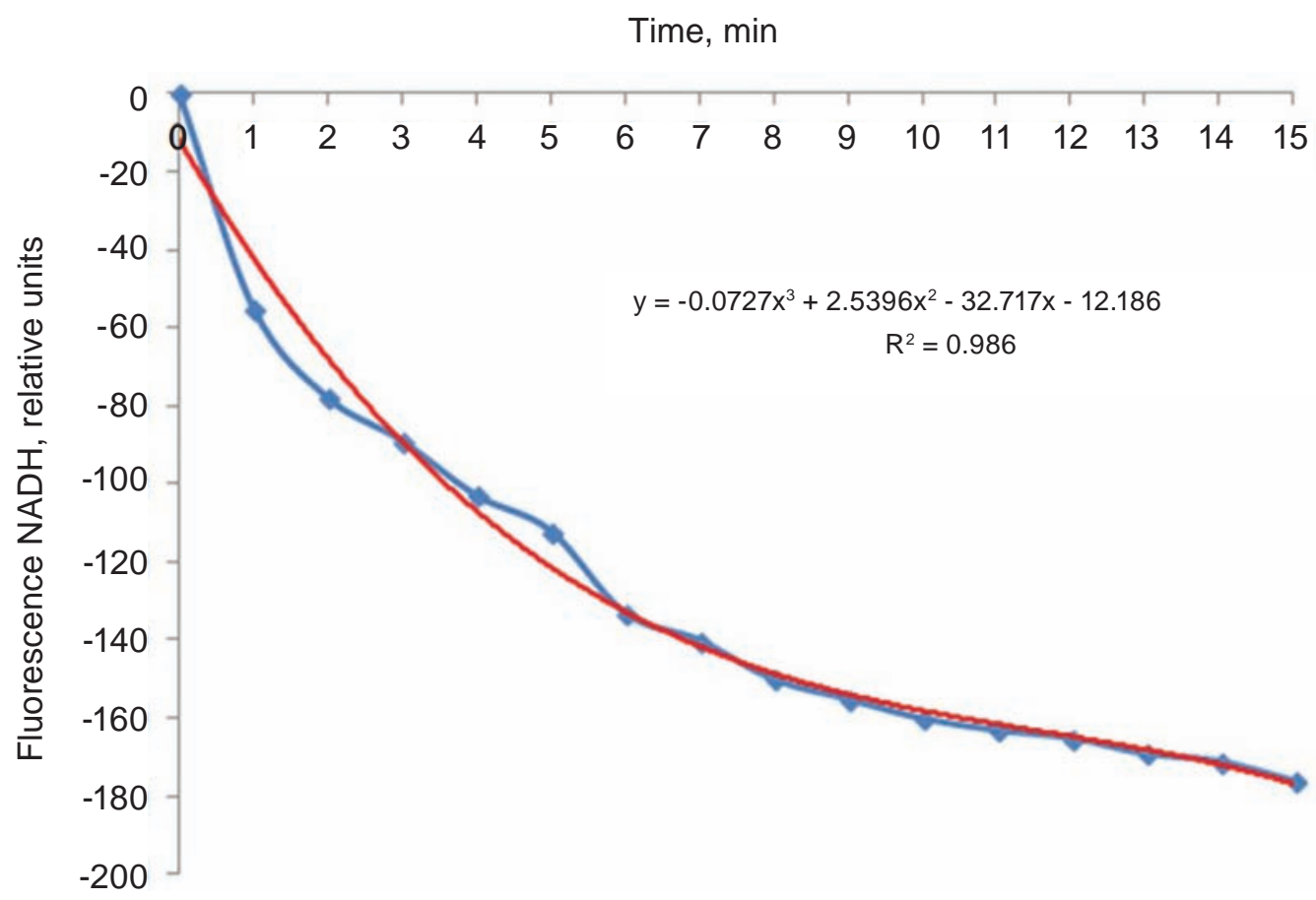

Fig. 2. Changes in fluorescence of NADH in the isolated mitochondria from the myometrium cells. These data represent a typical experiment

The intensity of the NADH fluorescent response:

$\mathrm{dFn} / \mathrm{dt}=-0.21 \mathrm{t}^{2}+5.1 \mathrm{t}-32.72$.

The concentration-time dependencies of the DCF fluorescence can be approximated by polynomials as:

$F n(\mathrm{DCF})=\left(-0.99 c^{2}+2.57 c+1.854\right) t+$

$+2.506 c+990.7$

where $c$ - concentration of sodium azide, $\mathrm{mM}, t-$ time, min.

The intensity of the DCF fluorescence:

$d F n / d t=-0.099 c^{2}+2.57 c+1.854$.

The obtained expressions make it possible to predict the time dependence of DCF fluorescence, for example, for $10 \mathrm{mM}$ concentration of sodium azide (Fig. 3):

$$
F n(\mathrm{DCF})=17.65 t+1015.8 \text {. }
$$

According to results for 1-7 $\mathrm{mM} \mathrm{NaN}_{3}$ (Fig. 4) dynamics of the concentration-dependent changes in the average values of mitochondria hydrodynamic diameter during swelling can be approximated as:

$$
\Delta D=(0.7 c+31) \ln (t)+16.6 c-39,
$$

where $c$ - concentration of sodium azide, $\mathrm{mM}, t-$ time, min.

So, the permeability of MPTP is described as:

$$
d(\Delta \mathrm{D}) / d t=(0.7 c+31) / t .
$$

It is possible to predict theoretically the course of the corresponding curves for unknown sodium azide concentrations based on this equation. Fig. 4 shows an example of such a curve for $10 \mathrm{mM}$ sodium azide.

Our model enabled a simultaneous prediction of the changes in the organelle NADH/DCF fluorescence and their hydrodynamic diameter in time, which enabled us to significantly optimize the time of the experimental procedures, the consumption of reagents, and the use of laboratory animals. Moreover, it allowed us to analyze the dynamics of the processes and compare the modeling results with the actual observations, considering the changes in the abovementioned parameters (the composition of the incubation medium and the presence of the activators/inhibitors).

Sodium azide is known to degrade in water solutions, producing hydrazoic acid, hydroxylamine, and, possibly, nitrogen oxides, which act as reactive nitrogen species in biological systems [12]. In our previous experiments, sodium azide $(5 \mathrm{mM})$ caused a more pronounced decrease in NADH fluorescence than in control, and also an increase in $\mathrm{FADH}_{2}$ contents, which may indicate blocking of electron transfer from succinate to ubiquinone [30]. We have at- 


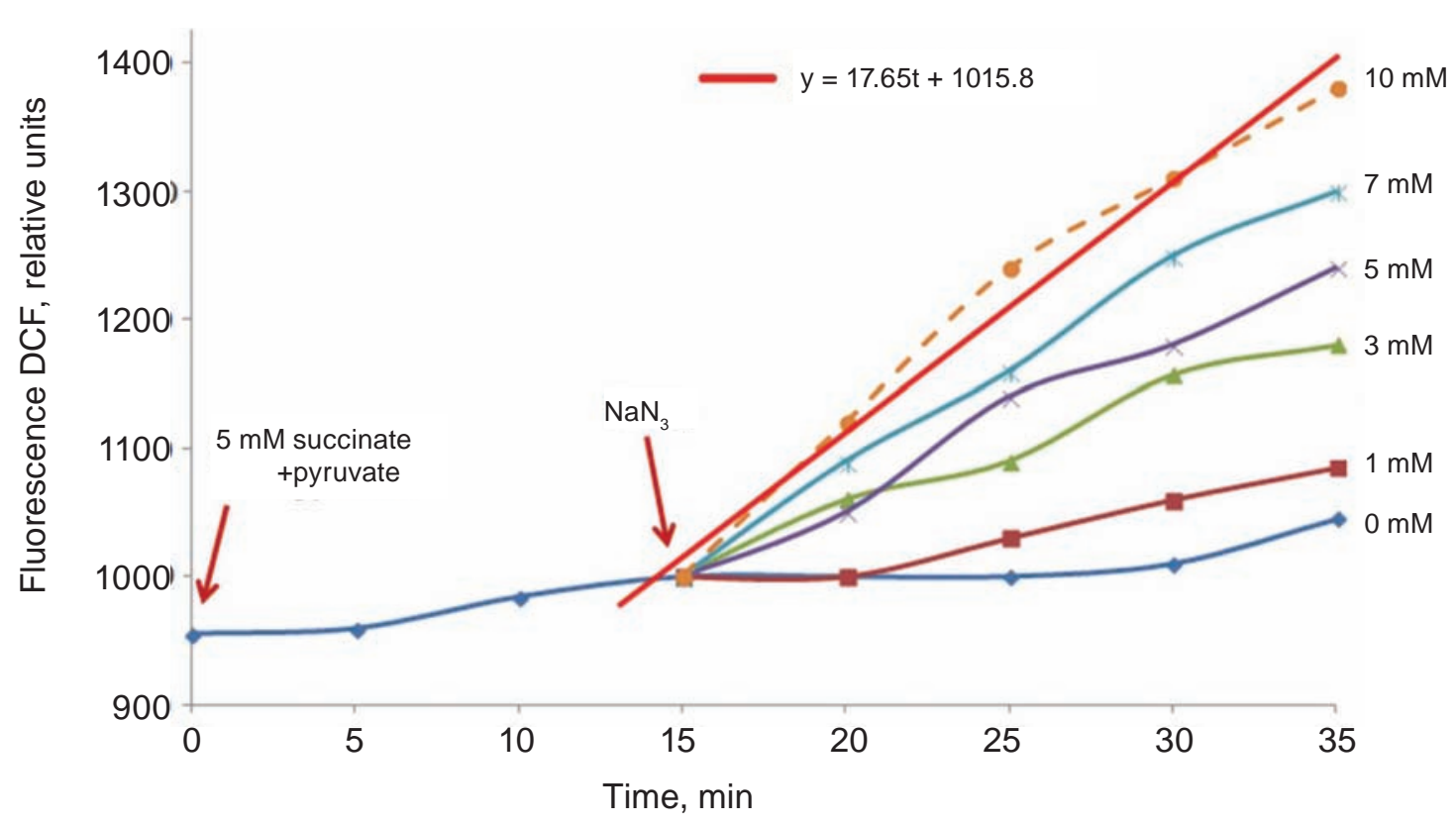

Fig. 3. The concentration-time dependencies of the DCF fluorescence in the isolated mitochondria. The straight red line is theoretically calculated according to equation (8) for $10 \mathrm{mM}$ sodium azide; dotted brawn line - experimentally obtained curve for $10 \mathrm{mM}$ sodium azide. These data represent a typical experiment

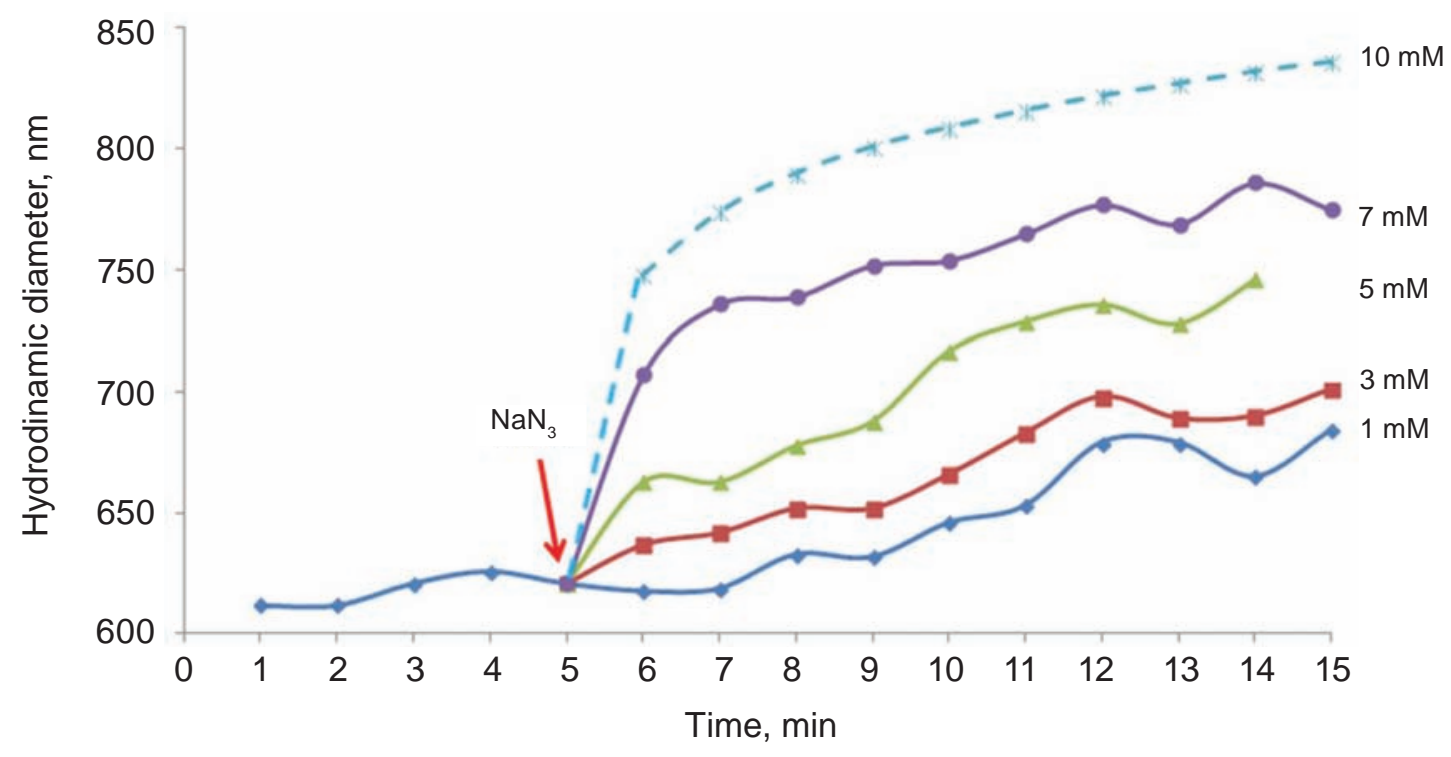

Fig. 4. The values of mitochondria hydrodynamic diameter during swelling on $\mathrm{NaN}_{3}$ action. The curve for $10 \mathrm{mM}$ sodium azide is theoretically calculated according to equation (9). These data represent a typical experiment

tributed the decreased NADH and FAD levels under nitrocompounds to drop in activity of enzymes of citric acid cycle due to inhibition of electron transport chain in mitochondrial membrane. Thus, we investigated with flow cytometry the effect of the sodium azide on matrix content of $\mathrm{Ca}$ ions in mi- tochondria to confirm the effect of $\mathrm{NO}_{\mathrm{x}}$ on the mitochondria functional activity (Fig. 5). Addition of exogenous $\mathrm{Ca}^{2+}$ to mitochondria suspension was associated with the increase in fluorescence of Fluo-4 that had been loaded into them in advance, which indicates increased matrix $\mathrm{Ca}^{2+}$ concentration. The 


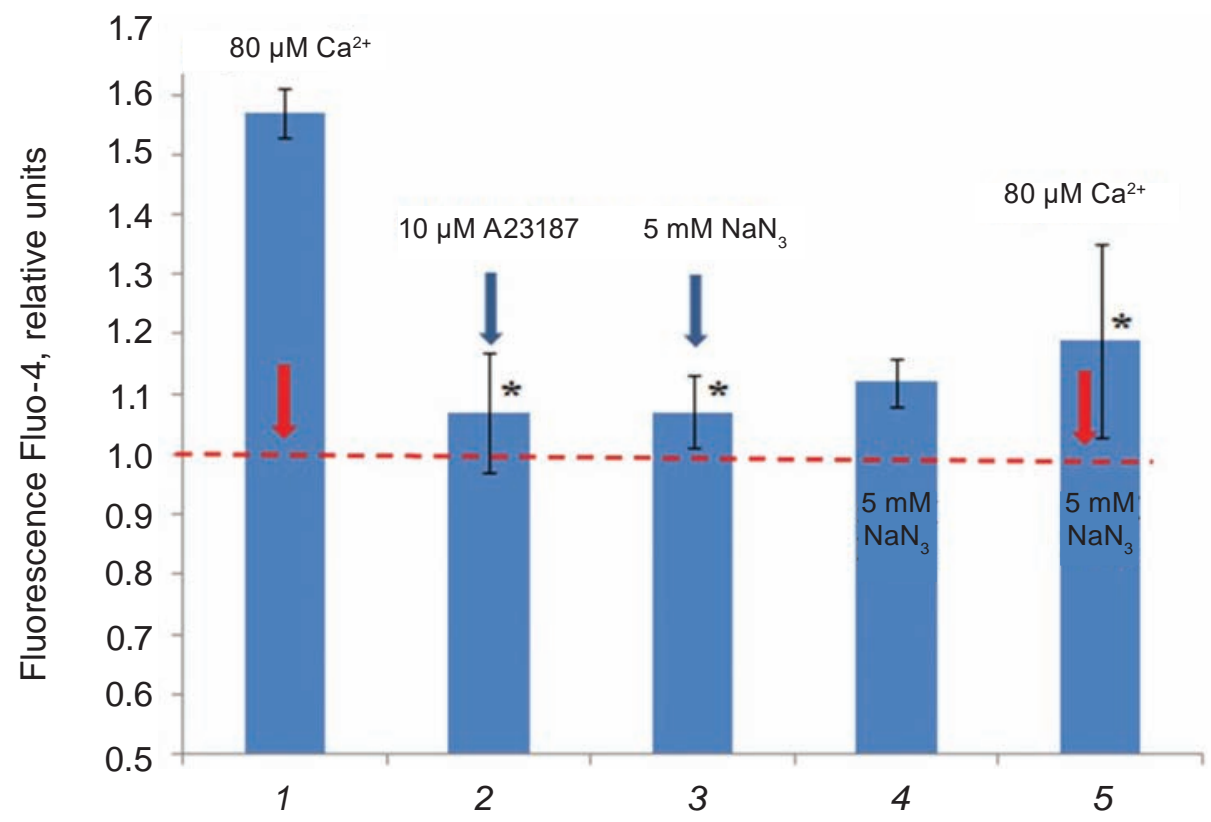

Fig. 5. Effects of $\mathrm{Ca}^{2+}$-ionophore and sodium azide on matrix $\mathrm{Ca}^{2+}$ content. The cation had been accumulated in an energy-dependent manner. Endogenous ionized Ca - “1”, starting level. The data are presented as mean $\pm S E M, * P \leq 0.05, n=5$

cation was accumulated in the presence of ${\mathrm{Mg}-\mathrm{ATP}^{2-}}^{2}$ and succinate for $5 \mathrm{~min}$, at which moment the stable level of $\mathrm{Ca}^{2+}$ accumulation was achieved (Fig 5, column 1). We ascertained the barrier function of mitochondrial inner membrane towards Ca ions by addition of A23187 $\mathrm{Ca}^{2+}$-ionophore to suspension. This was associated with rapid release of the accumulated cation (Fig 5, column 2). The sodium azide caused efficient release of accumulated $\mathrm{Ca}^{2+}$ from mitochondria (Fig 5, column 3). The de-energizing effect of sodium azide on mitochondria has been reliable established. The slight increase in ionized Ca in the matrix was observed, as well as a significant decrease in $\mathrm{Ca}$ accumulation in comparison with the control, under conditions of mitochondrial preincubation with sodium azide (depolarization of the internal membrane) (Fig. 5, column 4 and 5 respectively).

Thus, using the Petri nets, the simulation model for simultaneous changes in the fluorescence of endogenous NADH, the characteristic size of mitochondria, and the generation of reactive oxygen species under real experimental conditions has been created, which combines functional changes with the structural representation of these processes. The simulation results in mathematical equations that formalize simultaneous processes of mitochondrial swelling and DCF fluorescence in a medium with
$\mathrm{NaN}_{3}$. The de-energizing effect of sodium azide on mitochondria results in disturbance in their functioning, namely the ability to effectively accumulate and maintain $\mathrm{Ca}^{2+}$ in their matrix.

Conclusions. The simulation results in mathematical equations that formalize simultaneous processes of mitochondrial swelling, changes in NADH and DCF fluorescence in a medium in which $\mathrm{NaN}_{3}$ is presented. These equations are able to adequately describe the time and concentration characteristics of these processes, as well as predict the intensity of their occurrence. In particular, the response of mitochondria over time to the action of $\mathrm{NaN}_{3}$ in a concentration, that was not used in the experiment, was predicted. The calculated values of the studied biophysicochemical parameters were consistent with experimentally obtained data. The creation of an adequate model optimizes experimental procedures (time, costs of reagents and laboratory animals), allows analyzing the dynamics of processes and comparing experimental results with theoretical calculations provided that the composition of the incubation medium changes.

Conflict of interest. Authors have completed the Unified Conflicts of Interest form at http://ukrbiochemjournal.org/wp-content/uploads/2018/12/ coi_disclosure.pdf and declare no conflict of interest. 
Funding. This work was financed by research program of NAS of Ukraine "Biochemical mechanisms of control of systemic intercellular interactions and regulation of signal networks and cellular functions by norms and pathological conditions" (Registration No 0117U004344).

\section{ЗАСТОСУВАННЯ МЕТОДОЛОГІЇ МЕРЕЖ ПЕТРІ ДЛЯ ОЦІНКИ БІОФІЗИКО-ХІМІЧНИХ ПАРАМЕТРІВ ФУНКЦІОНУВАННЯ МІТОХОНДРІЙ}

\author{
Г. В. Данилович ${ }^{\bowtie}$ О. Ю. Чуніхін, \\ Ю. В. Данилович, С. О. Костерін
Інститут біохімії ім. О. В. Палладіна НАН України, Київ;
凶e-mail: danylovych@biochem.kiev.ua

Із використанням методології мереж Петрі розроблено математичну імітаційну модель, яка дозволяє прогнозувати одночасні зміни біофізико-хімічних параметрів функціонування мітохондрій. Модель взаємопов'язує зміни в часі гідродинамічного діаметра мітохондрій, функціонування електронного транспортного ланцюга, ендогенної флуоресценції нуклеотидів аденіну, сигналу флуоресценції DCF щодо продукування АФК та ефектів $\mathrm{NaN}_{3}$. Розраховані значення досліджуваних біофізико-хімічних параметрів відповідали експериментально одержаним даним. Модель дозволяє поєднати функціональні зміни мітохондрій та їх структурну репрезентацію, а також значно оптимізувати експериментальні умови.

К л ю ч о в і с л о в а: мережі Петрі, математичне моделювання, мітохондрії, електронтранспортувальний ланцюг, оксид азоту.

\section{References}

1. Bernardi P, Rasola A. Calcium and cell death: the mitochondrial connection. Subcell Biochem. 2007; 45: 481-506.

2. Graier WF, Frieden M, Malli R. Mitochondria and $\mathrm{Ca}^{2+}$ signaling: old guests, new functions. Eur J Physiol. 2007; 455(3): 375-396.

3. Orrenius S, Packer L, Cadenas E. (Eds.). Mitochondrial signaling in health and disease. N.Y.: CRC Press, 2012. 493 p.

4. Csordás G, Várnai P, Golenár T, Sheu SS, Hajnóczky G. Calcium transport across the inner mitochondrial membrane: molecular mechanisms and pharmacology. Mol Cell Endocrinol. 2012; 353(1-2): 109-113.

5. Szabadkai G, Duchen MR. Mitochondria: the hub of cellular $\mathrm{Ca}^{2+}$ signaling. Physiology (Bethesda). 2008; 23(2): 84-94.

6. Danylovych YuV, Karakhim SA, Danylovych GV, Kolomiets OV, Kosterin SO. Electrochemical potential of the inner mitochondrial membrane and $\mathrm{Ca}^{2+}$ homeostasis of myometrium cells. $\mathrm{Ukr}$ Biochem J. 2015; 87(5): 61-71.

7. Wang HW, Wei YH, Guo HW. Reduced nicotinamide adenine dinucleotide (NADH) fluorescence for the detection of cell death. Anticancer Agents Med Chem. 2009; 9(9): 10121017.

8. Heikal AA. Intracellular coenzymes as natural biomarkers for metabolic activities and mitochondrial anomalies. Biomark Med. 2010; 4(2): 241-263.

9. Brocard JB, Rintoul GL, Reynolds IJ. New perspectives on mitochondrial morphology in cell function. Biol Cell. 2003; 95(5): 239-242.

10. Kaasik A, Safiulina D, Zharkovsky A, Veksler V. Regulation of mitochondrial matrix volume. Am J Physiol Cell Physiol. 2007; 292(1): C157-C163.

11. Nowikovsky K, Schweyen RJ, Bernardi P. Pathophysiology of mitochondrial volume homeostasis: potassium transport and permeability transition. Biochim Biophys Acta. 2009; 1787(5): 345-350.

12. Iakovenko IN, Zhirnov VV. Sodium azide as indirect nitric oxide donor: researches on the rat aorta isolated segments. Ukr Biokhim Zhurn. 2005; 77(4): 120-123. (In Russia).

13. Wingender E. (Ed.). Biological Petri Nets. IOS Press; 2011. 316 p.

14. Kosterin SA, Bratkova NF, Kursky MD. The role of sarcolemma and mitochondria in calciumdependent control of myometrium relaxation. Biokhimiia. 1985; 50(8): 1350-1361. (In Russian).

15. Bradfor dMM. A rapid and sensitive method for the quantitation of microgram quantities of protein utilizing the principle of protein-dye binding. Anal Biochem. 1976; 72(1-2): 248-254.

16. Merkus HG. Particle size measurements. Fundamentals, practice, quality. Springer; 2009.

17. Nagasaki $M$, Saito A, Doi A, Matsuno $H$, Miyano S. Foundations of Systems Biology. Using Cell Illustrator and Pathway Databases. Springer; 2009. 
18. Kolomiets OV, Danylovych YuV, Danylovych GV, Kosterin SO. $\mathrm{Ca}^{2+}$ accumulation study in isolated smooth muscle mitochondria using Fluo-4 AM. Ukr Biokhim Zhurn. 2013; 85(4): 30-39. (In Ukrainian).

19. Chang S, Lamm SH. Human health effects of sodium azide exposure: a literature review and analysis. Int J Toxicol. 2003; 22(3): 175-186.

20. Ji D, Kamalden TA, del Olmo-Aguado S, Osborne NN. Light- and sodium azide-induced death of RGC-5 cells in culture occurs via different mechanisms. Apoptosis. 2011; 16(4): 425-437.

21. Feissner RF, Skalska J, Gaum WE, Sheu SS. Crosstalk signaling between mitochondrial $\mathrm{Ca}^{2+}$ and ROS. Front Biosci (Landmark Ed). 2009; 14: 1197-1218.

22. Santo-Domingo J, Wiederkehr A, De Marchi U. Modulation of the matrix redox signaling by mitochondrial $\mathrm{Ca}^{2+}$. World J Biol Chem. 2015; 6(4): 310-323.

23. Bernardi P, von Stockum S. The permeability transition pore as a $\mathrm{Ca}^{2+}$ release channel: new answers to an old question. Cell Calcium. 2012; 52(1): 22-27.

24. Trumpower BL. The protonmotive Q cycle. Energy transduction by coupling of proton translocation to electron transfer by the cytochrome bc1 complex. J Biol Chem. 1990; 265(20): 11409-11412.
25. Bringold U, Ghafourifar P, Richter C. Peroxynitrite formed by mitochondrial NO synthase promotes mitochondrial $\mathrm{Ca}^{2+}$ release. Free Radic Biol Med. 2000; 29(3-4): 343-348.

26. Gellerich FN, Gizatullina Z, Trumbeckaite S, Nguyen HP, Pallas T, Arandarcikaite O, Vielhaber S, Seppet E, Striggow F. The regulation of OXPHOS by extramitochondrial calcium. Biochim Biophys Acta. 2010; 1797(6-7): 1018-1027.

27. Elfering SL, Haynes VL, Traaseth NJ, Ettl A, Giulivi C. Aspects, mechanism, and biological relevance of mitochondrial protein nitration sustained by mitochondrial nitric oxide synthase. Am J Physiol Heart Circ Physiol. 2004; 286(1): H22-H29.

28. Rasola A, Bernardi P. Mitochondrial permeability transition in $\mathrm{Ca}^{2+}$-dependent apoptosis and necrosis. Cell Calcium. 2011; 50(3): 222-233.

29. Chance B, Williams GR. Respiratory enzymes in oxidative phosphorylation. III. The steady state. J Biol Chem. 1955; 217(1): 409-427.

30. Danylovych H, Chunikhin A, Danylovych Yu, Kosterin S. Methodology of Petri networks for simultaneous evaluation of the impact of different modifiers on the fluorescence of nucleotides from electron transport chain in isolated mitochondria and on the process of swelling. J Biotech Comput Biol Bionanotech. 2018; 99(1): 37-48. 